OPEN ACCESS

Citation: Rene Alfred Anton Bustamante, Maverick N. Tamayo, Wilbert Hetterscheid (2020) Rediscovery of a lost type: solving the mysterious identity of Amorphophallus longispathaceus Engl. \& Gehrm. (Araceae). Webbia. Journal of Plant Taxonomy and Geography 75(2): 287-292. doi: 10.36253/jopt-9446

Received: July 18, 2020

Accepted: August 12, 2020

Published: November 18, 2020

Copyright:@2020ReneAlfredAntonBustamante, Maverick N. Tamayo, Wilbert Hetterscheid. This is an open access, peer-reviewed article published by Firenze University Press (http://www. fupress.com/webbia) and distributed under the terms of the Creative Commons Attribution License, which permits unrestricted use, distribution, and reproduction in any medium, provided the original author and source are credited.

Data Availability Statement: All relevant data are within the paper and its Supporting Information files.

Competing Interests: The Author(s) declare(s) no conflict of interest.

Editor: Peter C. Boyce

\section{Rediscovery of a lost type: solving the mysterious identity of Amorphophallus longispathaceus Engl. \& Gehrm. (Araceae)}

\author{
Rene Alfred Anton Bustamante ${ }^{1}$, Maverick N. Tamayo ${ }^{2, *}$, Wilbert \\ HETTERSCHEID ${ }^{3}$ \\ ${ }^{1}$ Philippine Taxonomic Initiative, El Nido, Palawan, Philippines 5313 \\ ${ }^{2}$ Department of Biology, College of Science, University of the Philippines Baguio, Philip- \\ pines 2600 \\ ${ }^{3}$ National Tree Museum Gimborn, Velperengh 13, 3941BZ, The Netherlands \\ ${ }^{*}$ Corresponding author. Email: mntamayo@up.edu.ph
}

\begin{abstract}
The taxonomic identity of the incompletely described Amorphophallus longispathaceus Engl. \& Gehrm. has been a mystery for almost 109 years. Types were assumed destroyed during WWII, other than a sterile isotype at K, the recent discovery of a fertile isotype at NY, here designated the lectotype, has enabled the identity of this species to be clarified. Amorphophallus longispathaceus is conspecific with and takes priority over the more recent $A$. dactylifer Hett.
\end{abstract}

Keywords: Araceae, Amorphophallus, typification, Luzon, Mt. Apo, nomenclature.

\section{INTRODUCTION}

There are currently 17 species of Amorphophallus recognized for the Philippines (Pelser et al. 2011 onwards). Among these, three species whose holotypes were destroyed during WWII, remain poorly known viz., Amorphophallus luzoniensis Merr., A. merrillii K.Krause, and A. longispathaceus Engl. \& Gehrm. Amorphophallus luzoniensis was described using a specimen from Abulug river, Cagayan province (Merrill 1915). Duplicates of its destroyed holotype, Curran 19560, are still being searched for, and up to this writing, the identity of this species remains uncertain. A similar situation exists for Amorphophallus merrillii which was collected from Cavili island, Palawan province (Krause 1912), and its identity is presently being studied by the first author. Amorphophallus longispathaceus was described using a specimen from Todaya, Mt. Apo in Mindanao (Engler 1911). The protologue of this species was insufficient for confident identification with any known Amorphophallus species in the Philippines. Its holotype (R.S. Williams 2684 [wrongly quoted by Engler as 2654, the correct number mentioned by Merrill 1923 in: Enum. Philipp. Flow. Plants I: 179]) in PNH was destroyed during WWII. In Hetterscheid et al. (2020) an isotype is mentioned, which is 
preserved in $\mathrm{K}$. However, this is just a leaf fragment and proved insufficient for the authors to associate with any of the known or unidentified species in the Philippines. The protologue by Engl. \& Gehrm. in Engl., AraceaeLasioideae. Das Pflanzenr. IV. 23C, 1911: 91, does not unequivocally identify any Philippine species known to date. Therefore, Hetterscheid et al. 2020 decided to not consider this name in their paper. But fortunately, an isotype of Amorphophallus longispathaceus was discovered recently by the first author in NY, solving the mystery behind its almost forgotten name and identity.

We here designate the NY sheet of R.S. Williams 2684 with the inflorescence as the lectotype of the name A. longispathaceus following article 9.3 and 9.12 of the Shenzhen Code (Turland et al. 2017). The rediscovered isotype contains a full inflorescence and closely matches the more recent Amorphophallus dactylifer Hett. which we now place in the synonymy of the older name. Meanwhile, the second sheet at NY with the same number but with a leaf fragment is not included in the lectotype choice (here designated as paratype) because it is a separate gathering of another plant, since in this species (and most others of the genus) leaf and inflorescence do not appear simultaneously on the same plant. We do acknowledge though that it is indeed an original material, and taxonomically it is quite certain that it is the leaf of the same species. An updated description of Amorphophallus longispathaceus is provided using the protologue of $A$. dactylifer (Hetterscheid 1994) including a supplementary description by Magtoto et al. 2013, and observations from live specimens.

\section{TAXONOMIC TREATMENT}

Amorphophallus longispathaceus Engl. \& Gehrm. in Engl. Araceae-Lasioideae. Pflanzenr. IV. 23C, 1911: 91

Type: Todaya, Mt. Apo, Mindanao, Philippines, 05 April 1905. R.S. Williams 2684 [holotype; PNH (lost); iso, K! (leaf fragment), NY!; lectotype here designated: R.S. Williams 2684, New York Botanical Garden Herbarium sheet NY03774120 (Figures 1 \& 2), NY!; paratypes, R.S. Williams 2684, NYBG sheet NY03774118 (Figure 3)].

(=) Amorphophallus dactylifer Hett. in Blumea 39(1/2), 1994: 252, syn. nov.

Type: Luzon, San Mariano, Isabela, Sierra Madre Mts., Bo. Disulap, undergrowth in Nabulay Forest, Philippines, 18 May 1961. H.G. Gutierrez PNH 78180 (holotype, $\mathrm{L})$.

\section{Description}

Tuber depressed globose, 3-9 $\mathrm{cm}$ long $\times 7-16 \mathrm{~cm}$ wide. Leaf solitary, lamina diameter ca. $180 \mathrm{~cm}$; petiole background color greyish green (light to dark reddish when young), ca. $140 \mathrm{~cm}$ long $\times 2-6 \mathrm{~cm}$ wide, smooth; petiole markings elongate-elliptic with whitish or green spots, the latter with a whitish margin, those at the base of the petiole strongly raised, crust-like, upper part of petiole with obscure, dark reddish brown, narrowly elliptic to near linear spots; rachis winged distally from the basal branching, basal part naked with a few petiolulate leaflets; leaflets elliptic or elliptic-lanceolate, 16-18 $\mathrm{cm}$ long $\times 5-6 \mathrm{~cm}$ wide, long acuminate (acumen up to $3 \mathrm{~cm}$ long). Inflorescence solitary, long peduncled; peduncle almost the same coloration and marking with petiole, $60-130 \mathrm{~cm}$ long $\times 1-3.5 \mathrm{~cm}$ wide; spathe campanulate, $30-38 \mathrm{~cm}$ long $\times 12-20 \mathrm{~cm}$ wide, elongate triangular, acute, base strongly convolute, limb arching over; outside of spathe brown with white spots, smooth, entire, membranaceous; inside of base dark purple with pale upper part, densely clothed with short and long, simple or branched, fleshy or flaky, purple to reddish or brown finger-like warts, especially near the base of the spadix. Spadix sessile, at most twice as long as the spathe, $42-60 \mathrm{~cm}$ long $\times 2-3 \mathrm{~cm}$ wide; female zone cylindric, $4-8.5 \mathrm{~cm}$ long $\times 2-4 \mathrm{~cm}$ wide, flowers slightly distant; male zone elongate obconic or cylindric, $4.5-6.5 \mathrm{~cm}$ long $\times 1.5-3 \mathrm{~cm}$ wide at the top, flowers congested; appendix elongate conic, top obtuse, acute or subacute, $31-46 \mathrm{~cm}$ long $\times 2-3 \mathrm{~cm}$ wide at the base, gradually tapering to the tip, smooth, dark brownish, red or purple. Ovaries subglobose or depressed globose, $2-2.5 \mathrm{~mm}$ long $\times 2-3 \mathrm{~mm}$ wide, unilocular; style reddish or brown, $2-5 \mathrm{~mm}$ long $\times$ 0.8-1 mm wide; stigma large, brown or dark red, 1-1.5 $\mathrm{mm}$ long $\times$ ca. $2 \mathrm{~mm}$ wide, oval in cross section, shallowly or deeply 2- or 3-lobed, lobes rounded or conic, appearing claw-like, surface with numerous large conic fleshy projections. Male flowers consisting of 2-3(-5) stamens; stamens reddish, 1-1.5 mm long; filaments $0.1-0.5$ $\mathrm{mm}$ long, connate; anthers ca. $1 \times 1.5-2.5 \mathrm{~mm}$, truncate, pores apical, elongate. Pollen psilate.

\section{Distribution}

Philippines: Luzon, Sierra Madre Mountains, San Mariano, Bo. Disulap, ca. 152 m (Hetterscheid 1994), Municipality of Palanan, Isabela Province (J.M. Agcaoili pers. obs.); Mt. Makiling, Los Banos, Laguna Province; San Narciso, Zambales Province; Visayas, Samar; Mindanao Todaya, Mt. Apo; Mt. Kabatuan, Surigao Province (Hetterscheid 1994). 


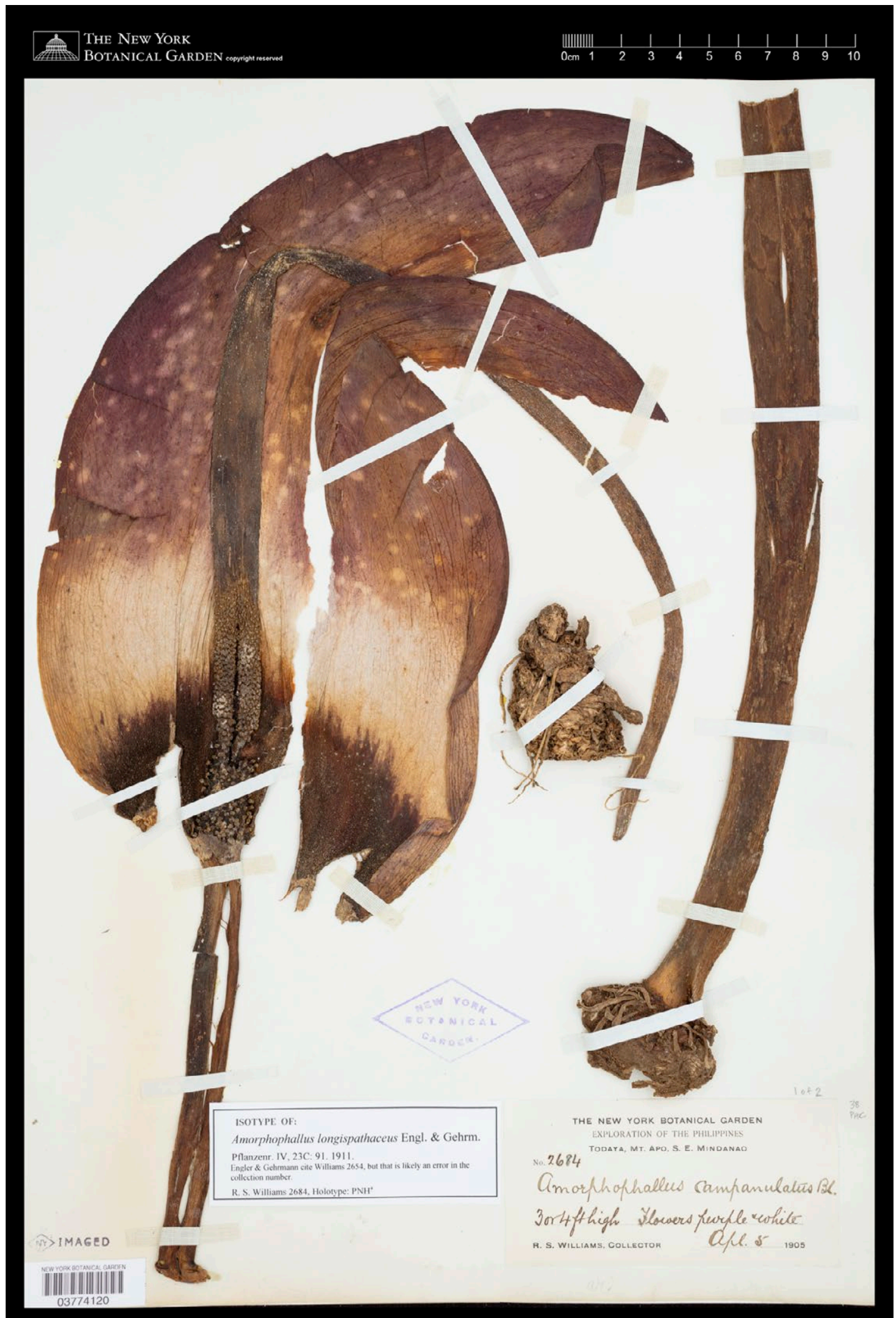

Figure 1. Lectotype of Amorphophallus longispathaceus Engl. \& Gehrm. (NY03774120). (Image courtesy of the C.V. Starr Virtual Herbarium of the New York Botanical Garden http://sweetgum.nybg.org/science/vh/). E-loan No.: 25991. 


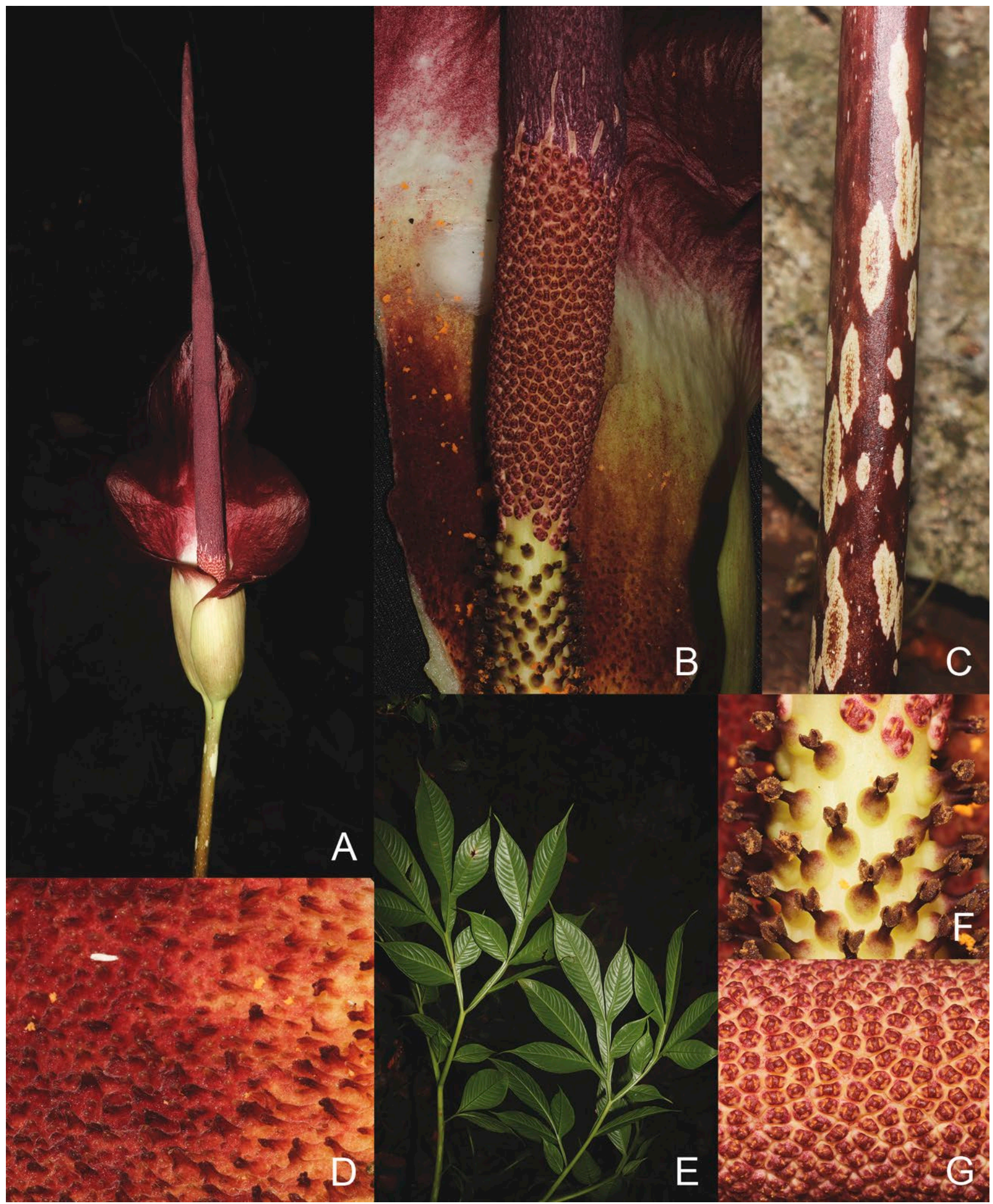

Figure 2. “Amorphophallus dactylifer Hett." i.e. A. longispathaceus Engl. \& Gehrm. from Palanan, Isabela, Luzon Island, Philippines. A. Inflorescence; B. Details of the male and female zones; C. Peduncle detail; D. Inside detail of the spathe base; E. Leaves; F. Detail of stigmas, styles and ovaries; G. Detail of the stamens. (Photos by J.M. Agcaoili). 


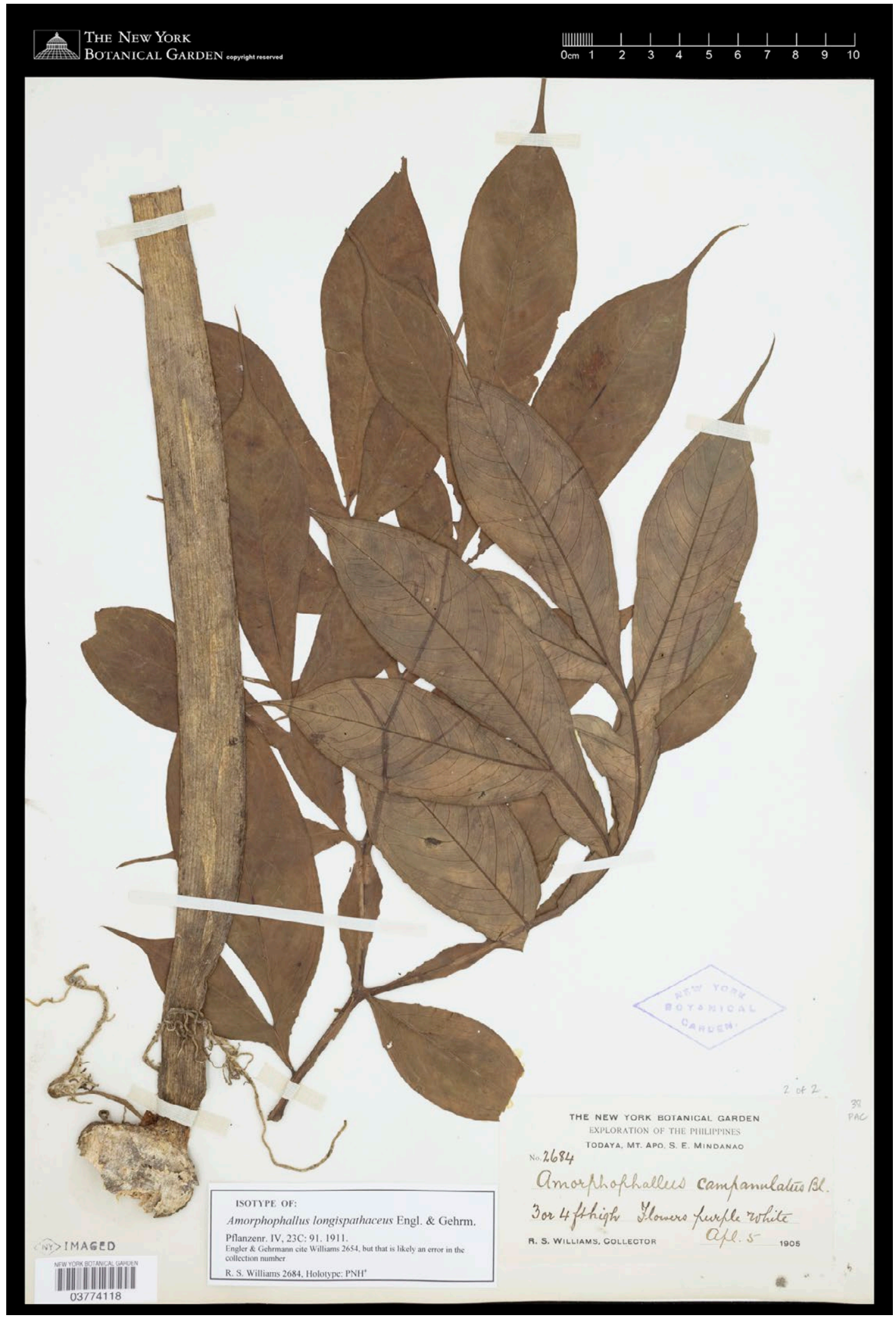

Figure 3. Paratype of Amorphophallus longispathaceus Engl. \& Gehrm. (NY03774118). (Image courtesy of the C.V. Starr Virtual Herbarium of the New York Botanical Garden http://sweetgum.nybg.org/science/vh/). E-loan No.: 25991. 


\section{Phenology}

Flowering: June-July; Fruiting: late July-August.

Notes

The lectotype of Amorphophallus longispathaceus is clearly identifiable as $A$. dactylifer with the peduncle much longer than spathe, style longer than $2 \mathrm{~mm}$, spathe almost as broad as long, and the spadix at most twice as long as the spathe.

\section{ACKNOWLEDGEMENTS}

We thank Amy Weiss, Collections Manager, William and Lynda Steere Herbarium, New York Botanical Garden, New York, USA for her invaluable help in scanning, and allowing the authors to use the image of A. longispathaceus. The Mabuwaya Foundation, Inc. is thanked for their technical and logistical support during the Palanan fieldwork. Special thanks to Mr. John Michael Agcaoili for allowing the authors to use his $A$. longispathaceus photos; to Mr. Adriane Tobias for his kind assistance, and to the Philippine Taxonomic Initiative, Inc. (phtaxa.org) for bringing together the expertise of the researchers involved in this study. Anonymous reviewers are also thanked for their valuable comments and suggestions that improved this manuscript.

\section{REFERENCES}

Engler A. 1911. Araceae-Lasioideae. Das Pflanzenreich, Regni vegetabilis conspectus. IV: 23C: 91. Engelmann: Leipzig.

Hetterscheid WLA. 1994. Notes on the genus Amorphophallus (Araceae) -2. New species from tropical Asia. Blumea. 39: 237-281.

Hetterscheid WLA, Medecilo MP, Callado JRC, Galloway A. 2020. New species of Amorphophallus (Araceae) in the Philippines and an updated key. Blumea. 65: 1-9.

Krause K. 1912. Zwei neue Araceen von den Philippinen. Notizblatt des Königl. botanischen Gartens und Museums zu Dahlem bei Steglitz (Berlin). 5: 266-267.

Magtoto LM, Mones DG, Ballada KA, Austria CM, Dizon RM, Alangui WV, Reginaldo AA, Galvan WM, Dizon KT, Hetterscheid WLA. 2013. Amorphophallus adamsensis (Araceae), a new species from Ilocos Norte, Philippines. Blumea. 58: 267-270.

Merrill ED. 1915. New or noteworthy Philippine plants, X. Philippine Journal of Science, section C, Botany. 10: 287-349.
Merrill ED. 1923. An enumeration of Philippine flowering plants. Volume 1. Bureau of Science, Manila.

Pelser PB, Barcelona JF, Nickrent DL. (Eds.) (2011 onwards). Co's Digital Flora of the Philippines. Available from: www.philippineplants.org (accessed 12 June 2020).

Turland NJ, Wiersema JH, Barrie FR, Greuter W, Hawksworth DL, Herendeen PS, Knapp S, Kusber W-H, Li D-H, Marhold K, May TW, McNeill J, Monro AM, Prado J, Price MJ, Smith GF. (ed.) 2018. International code of nomenclature for algae, fungi and plants (Shenzhen Code) adopted by the Nineteenth International Botanical Congress Shenzhen, China, July 2017. Regnum Vegetabile. 159: 1-227. 